\title{
ZAPOMNIANY DWÓR GORAJSKICH PRZY UL. BERNARDYŃSKIEJ 12 W LUBLINIE
}

\author{
Krzysztof Janus \\ Wydział Budownictwa i Architektury, Katedra Architektury Urbanistyki \\ i Planowania Przestrzennego, Politechnika Lubelska \\ e-mail: k.janus@pollub.pl
}

\begin{abstract}
Streszczenie: W pracy opisano skomplikowaną i bujną historię budynku dawnego dworu Gorajskich przy ul. Bernardyńskiej $12 \mathrm{w}$ Lublinie. Uwzględniono powszechnie znane fakty i dokumenty historyczne z życia budynku jak i te dopiero poznane. Przy uwzględnieniu istniejących prac badawczych i projektów oraz oględzin i badań własnych udało się wykonać analizę architektoniczną, z wykonaniem rozwarstwienia i określenia faz przekształceń budynku. Praca ta pozwoliła na umieszczenie dworu Gorajskich jako jednego z zapomnianych ale ciągle zachowanych dworów magnackich powstałych w XVII wieku na lubelskim Żmigrodzie.
\end{abstract}

Słowa kluczowe: Dwór Gorajskich, badania architektoniczne, wąwóz przy ul. Bernardyńskiej, ul. Bernardyńska

Artykuł powstał w ramach badań prowadzonych przez autora Uczestnika projektu: „Kwalifikacje dla rynku pracy Politechnika Lubelska przyjazna dla pracodawcy” współfinansowanego przez Unię Europejską w ramach Europejskiego Funduszu Społecznego. Participants of the project: "Qualifications for the labour market - employer friendly university", cofinanced by European Union from European Social Fund.

\section{HISTORIA BUDYNKU}

Pierwsze wzmianki na temat obiektu pochodzą z 1602 r. ${ }^{1}$ i mówią o dworze Gorajskich $\mathrm{z}$ Goraja ${ }^{2}$. Nie jest pewne kto z rodu nabył dobra lubelskie ale uwzględniając wszystkie zebrane dane, sądzić można, że był nim Adam³. On to zapewne rozpoczął budowę dworu i utworzył jurydykę Gorajszczyzna. Po śmierci swego teścia (Stanisława Słupeckiego - kasztelana lubelskiego) Adam w 1575 obejmuje stanowisko przywódcy kalwinów lubelskich a pięć lat wcześniej udostępnia swoją kamienicę na potrzeby zboru. Sporządzona w 1656 roku lustracja Lublina nie wymienia obiektu. Na tej podstawie można przyjąć, że dwór wzniesiony został pomiędzy 1565 , a 1570 rokiem ${ }^{4}$.

Biorąc pod uwagę lokalizację budynku poza murami miejskimi, majętność i stanowiska piastowane przez właściciela można wnioskować, że obiekt w początkowej fazie swego istnienia pełnił funkcję mieszkalno-obronne (podobnie jak zlokalizowany opodal pałac Parysów, czy pałac Sobieskich). Był on traktowany przez Gorajskich jako okazjonalnie wykorzystywana rezydencja w trakcie ważniejszych wydarzeń rangi miejskiej, regionalnej czy krajowej

1 B. Winiarczyk, W. Boruch, Kamienica przy ul. Bernardyńskiej 12 w Lublinie, Rozpoznanie historyczne, 1994, str. 2.

2 Rodzina Gorajskiskich w tym okresie była znana, majętna i sięgała daleko zakresem swych wpływów, piastowała również wyższe stanowiska państwowe Adam Gorajski (? - 1602 r.), poseł na sejm, deputat do trybunału Koronnego, marszałek sejmiku województwa lubelskiego, przywódca kalwinów lubelskich,Rafał Gorajski (? - 1660r.) - stolnik lubelski,Zbigniew Gorajski (1590-1655), marszałek sejmiku województwa lubelskiego, kasztelan kijowski, kasztelan chełmski, Władysław Rej (1612-1682) - spadkobierca Zbigniewa, wojewoda lubelski.

3 Poseł na sejm, deputat do trybunału Koronnego, marszałek sejmiku województwa lubelskiego, przywódca kalwinów lubelskich, w początkowym okresie był zwolennikiem polityki Jana Zamojskiego, jeździł z nim bronić granic przed Tatarami, później sądził się z nim o dobra biłgorajskie.

4 Na podstawie zastosowanych materiałów i technologii, wydaje się, że obiekt powstał znacznie wcześniej. 
oraz jako „serce” jurydyki ${ }^{5}$. Dopiero w miarę awansu społecznego i finansowego obiekt był rozbudowywany i przekształcany, jednak nigdy nie pełnił funkcji siedziby rodowej.

Wiadomym jest, że po śmierci swego teścia Adam Gorajski został przywódcą kalwinów lubelskich, a w 1570 roku udostępnił swoją kamienicę na potrzeby zboru. Nie jest pewne jak wyglądała ona w tym okresie i jak długo służyła na te potrzeby. Przypuszczać można, że funkcja ta wymusiła pewne zmiany i modyfikacje.

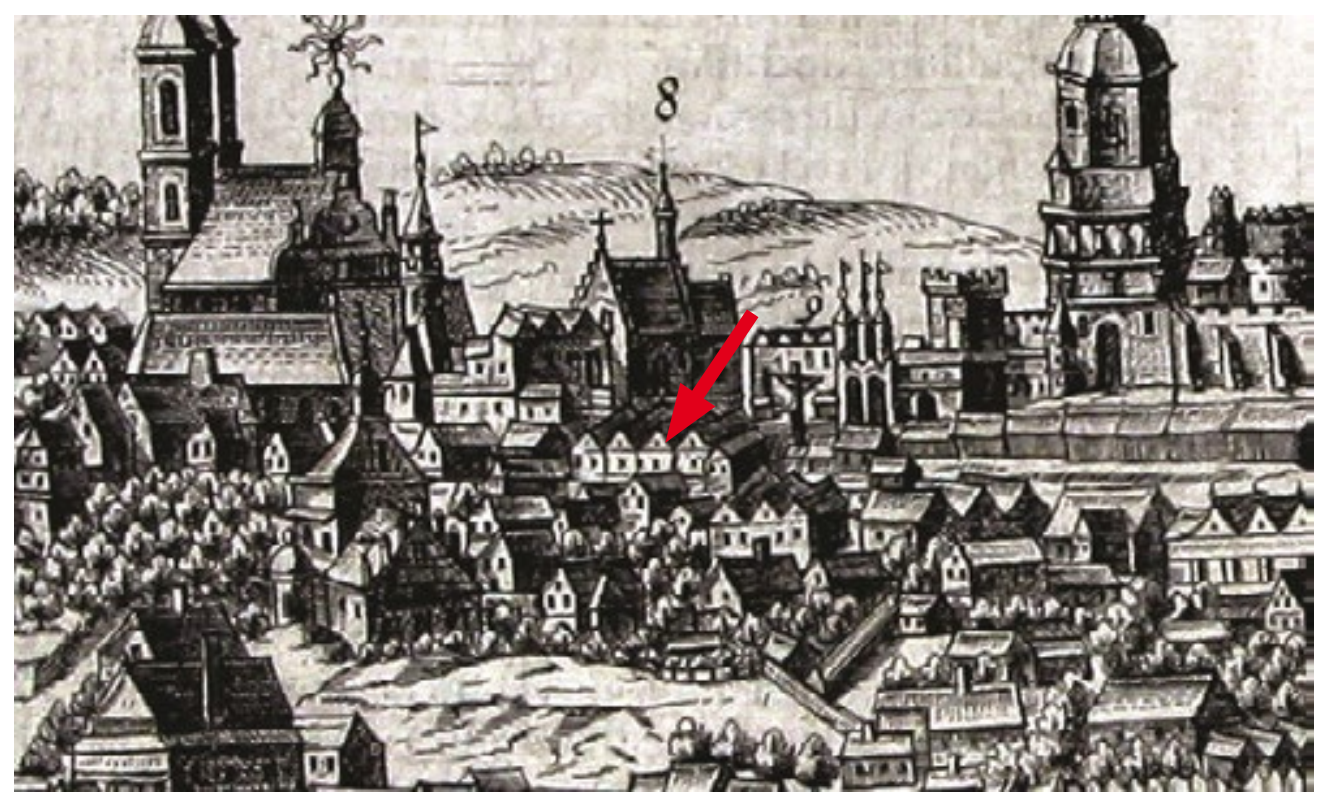

Ryc. 1. Fragment Lublina z dzieła Brauna z 1617 r. - strzałką oznaczono możliwą lokalizację obiektu

Fig. 1. Part of the Lublin from Braun's engraving 1617 - the arrow was marked possible location of the object

Po raz pierwszy obiekt został przedstawiony na sztychu Hogenberga/Brauna, wydanym w $1617 \mathrm{r}^{6}$, jako budynek $\mathrm{z}$ dachem dwuspadowy i trójkątnym szczytem, dwoma oknami (prawdopodobnie ponad parterem), oraz podziałem poziomym ${ }^{7}$, był szczytowo lokowany względem ulicy (podobnie jak pozostałe budynki ulicy). Oczywiście istnieje pewne prawdopodobieństwo, że przedstawiony obiekt jest tylko „tłem” dla ogólnego widoku, jednak analogie te nie wydają się być przypadkowe, a odwzorowanie wierne. Układ budynku przedstawiony na sztychu jest adekwatny do układu części „D”.

Pierwsze „dokładne” graficzne przedstawienie obiektu zawdzięczamy Karolowi Bekiewiczowi, który $\sim 1649$ roku utrwalił na planie tą część Lublina. Dwór ukazany został jako obiekt dwukondygnacyjny z dachem pokrytym dachówką, siedmioosiowy z wydatnym ryzalitem i dwoma niesymetrycznymi skrzydłami, wydaje się być on murowany (Ryc. 2).Od ulicy Królewskiej prowadziła niewielka uliczka nazwana „Ławki Bernardyńskie”, która w początkowym swym biegu przedstawiona została $\mathrm{w}$ formie drewnianego trapu, obniżającego się stopniowo,

5 W 1649 r. zajmowała ona powierzchnię ok. 40 a.

6 Rok wydania dzieła znacznie odbiega od daty powstania widoku. Wzorując się tylko opisem odnoszącym się do Marka Sobieskiego wnioskować można, że widok powstał za jego życia, kiedy ten był wojewodą lubelskim (1599-1605). Wiadomym jest również, że Marek kupił dwór, który zapewne przebudował w 1601 roku, co zawęża okres jego powstania na lata pomiędzy 1601, a 1605.

7 Lokalizacja obiektu została określona na podstawie analizy zabudowań poza murami miejskimi, tej części Lublina. 
aż do „rynsztoku”, nad którym wiodła drewniana kładka. Autor nie przedstawił w sposób jednoznaczny ukształtowania terenu, jednak wydaje się, że obiekt od ul. Królewskiej oddzielał niewielki wąwóz. Na planie tym przedstawia również granicę jurydyki Gorajszczyzna.
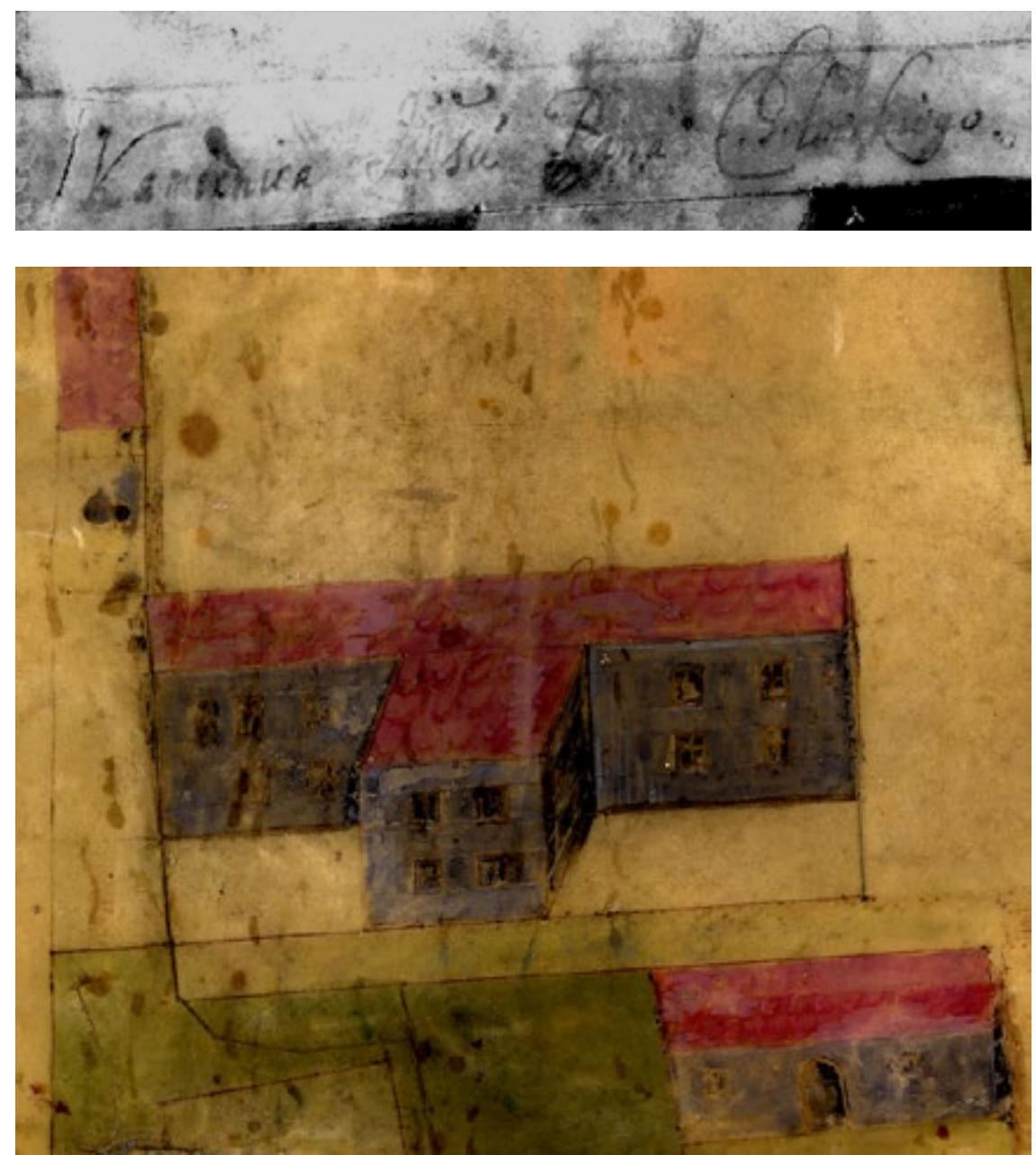

Ryc. 2. Fragment planu K. Bekiewicza z ok. 1649 r. z przedstawieniem omawianego obiektu opisanym jako „Kamienica Imści Pana Chełmskiego”, Dział Zbiorów Specjalnych, WBPE

Fig. 2. Fragment of the Bekiewicz's plan 1649 with object and description „Kamienica Imści Pana Chełmskiego”

Kolejna informacja pochodzi dopiero z XVIII wieku i mówi o dworze Gorajskich na Gorajszczyźnie ${ }^{8}$. Wiadomym jest również, że ostatnim „Gorajskim” właścicielem obiektu był Zbigniew, którego dziedzictwo przeszło w ręce Władysława Reja. Informacja ta w pewnym stopniu sugeruje brak znacznych zmian i przekształceń po zmianie właściciela9

8 Informacja ta stwierdza fakt istnienia obiektu, nie wnosi żadnych danych na temat funkcji, wielkości czy jego wyglądu.

9 Zazwyczaj przy znacznych przekształceniach, obiekt przyjmował nazwę od właściciela, który go przebudował lub w innym stopniu zasłużył się w regionie, czy kraju. 
Po raz pierwszy obiekt na planie przedstawił J. N. Łęcki w 1783 r., na znanych jego kopiach z 1802 i 1852 r. budynek ukazany został w formie prostokąta przylegającego do budynku klasztoru ss. bernardynek. Oznaczony jest jako „f 3” z opisem ,rudera”.

Planem z ok. 1865 roku ukazuje obiekt $\mathrm{z}$ bliżej nieokreślonym ryzalitem/portykiem od frontu.

Przedstawienie wykonane przez A. Lerue z 1857 roku ukazuje niewielki fragment elewacji frontowej. Obiekt jest tylko tłem dla głównego elementu działa, którym jest kościół Bernardynów ${ }^{10}$.

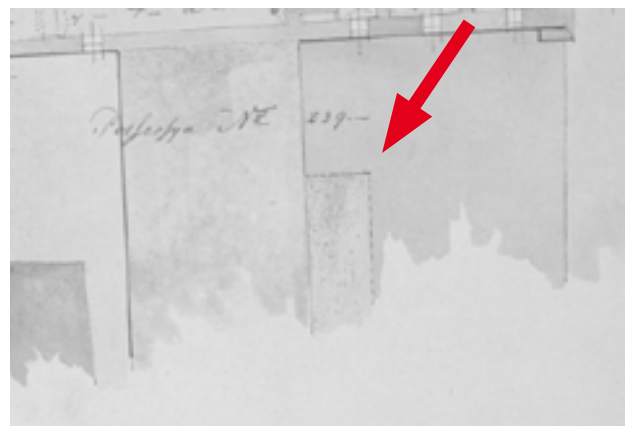

Ryc. 3. Fragment planu z zaznaczeniem budynku prawdopodobnie z portykiem (XIX w., oryginał nieznany), strzałką oznaczono „balkon na filarach”

Fig. 3. Fragment of the plan with building, the arrow was marked ,balcony on pillars,

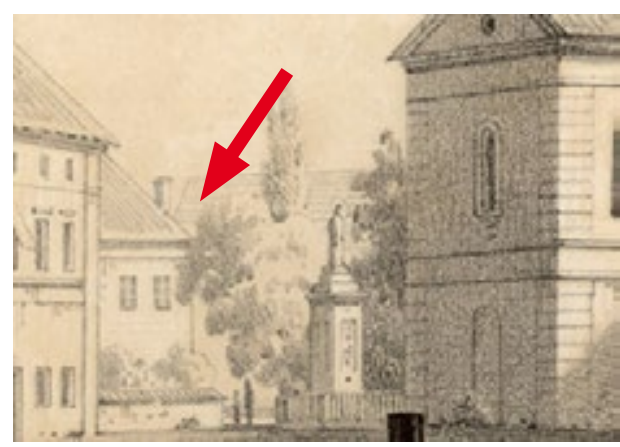

Ryc. 5. Fragment obrazu przedstawiający kościół Bernardynów - w tle widoczna kamienica (oznaczona strzałką), A. Lerue, 1854

Fig. 5. Fragment painting of the Bernardyn's church in background visible tenement, A. Lerue, 1854

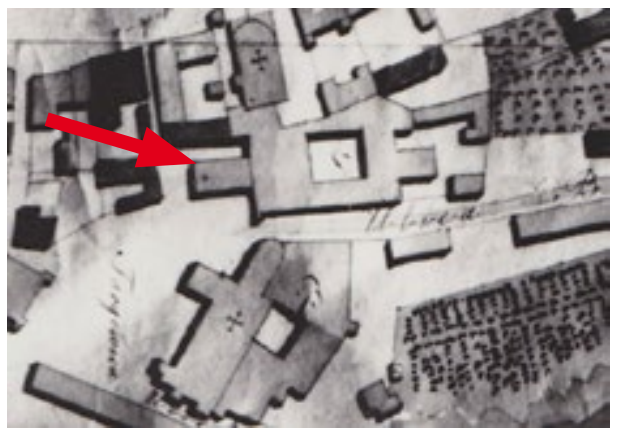

Ryc. 4. Fragment mapy Lublina z zaznaczonym obiektem $\mathrm{z} \sim 1852$ r. (autor nieznany) Fig. 4. Fragment map of the Lublina with noted object $\sim 1852$

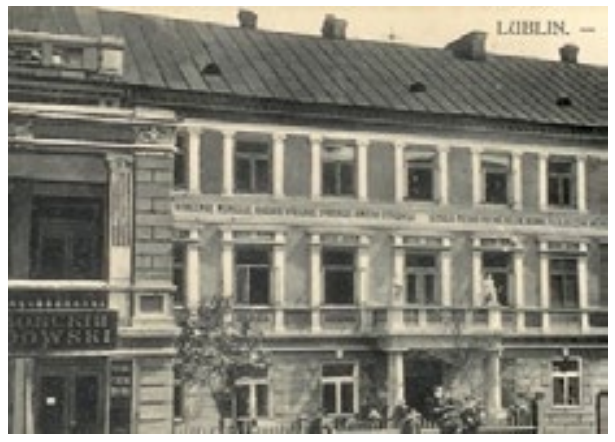

Ryc. 6. Pocztówka przedstawiająca budynek Bernardyńska 12 - szkoła Staszica ( 1910 r.)

Fig. 6. Postcard representative building Bernardyńska 12 - Staszic's school ( 1910)

XX-to wieczne fotografie i pocztówki, przedstawiają już obiekt w pełni ukształtowany, odpowiadający obecnej formie z niewielkimi zmianami.

Wszystkie informacje, jakie udało się pozyskać na temat wyglądu obiektu, pomiędzy XVI a XIX wiekiem, pochodzą z historycznych rycin i planów. Więcej informacji przynosi dopiero wiek XIX-ty i opisy sprzedaży. W 1823 r. obiekt na publicznej licytacji kupił Dominik

10 Widomym jest, że rysunki wykonane przez Lerue precyzyjnie przedstawiają główny obiekt, jeżeli chodzi o otoczenie i tło, budzi wiele zastrzeżeń a raczej stanowi wypełnieni, które często nie jest wiarygodne. 
Boczarski ${ }^{11}$. Budynek w tym okresie był murowany, kryty gontem, podpiwniczony z sienią, dwoma izbami, dwoma pokojami, „sionką” i kuchnią na piętrze. Siedem lat później właścicielem obiektu był Jan Boczarski, później Ludwika Boczarska. Nie zachowały się żadne wzmianki na temat prac budowlanych w okresie Boczarskich ale przypuszczać można, że ograniczały się one do bieżących napraw i remontów. W 1858 roku powstał pierwszy dokładny opis sporządzony na potrzeby ubezpieczenia pożarowego. Posesja składa się w tym okresie z domu murowanego dwukondygnacyjnego, pokrytego dachówką holenderką oraz z drewnianej stajni i drwalni. Na parterze domu znajdowała się kuchnia i sień ze stropem $\mathrm{z}$,tarcic calowych”, kilku pokoi, z których jeden „po lewej stronie” posiadał strop na trzcinie i posadzkę „krzyżową z fryzami”. Na piętro prowadziły schody o dziewiętnastu stopniach z balustradą i galerią. Układ kondygnacji „dwie ściany poprzeczne, jedna podłużna” odpowiada zapewne temu dzisiejszemu ${ }^{12}$. Wysokość pomieszczeń kondygnacji $375 \mathrm{~cm}$, również zgadza się z obecnym. Na parterze znajdowało się sześć okien dubeltowych, jedno okna pojedyncze w kuchni, drzwi frontowe, dwuskrzydłowe, tambur ${ }^{13}$ przy drzwiach na tył, dwa piece kaflowe, jeden piecyk okrągły, kuchnia angielska, kominek szafiasty z blachą. Na pierwszym piętrze znajdowała się sień, kuchnia i spiżarnia z „podsufitką na zakład” i podłogą drewnianą. W pozostałych pokojach „strop trzcinowy” oraz podłoga „krzyżowa z fryzami dębowymi”. Na poddasze prowadziły schody o siedemnastu stopniach. Od frontu znajdował się balkon na czterech filarach z galerią i podłogą drewnianą, od tyłu „ganek w stanie złym”. Na kondygnacji znajdowało się dziewięć okien dubeltowych, dwa okna pojedyncze, drzwi na balkon, drzwi „ordynaryjne” na ganek od tyłu, drzwi wewnętrzne, tambur w sieni, dwa piece kaflowe, dwa piece kaflowe mniejsze, jeden piecyk ceglany, kuchnia z „blatem żelaznym” i fajerkami ${ }^{14}$. Cały ten opis dokładnie odwzorowuje układ budynku w tym okresie, z wyraźnymi cechami obecnej zabudowy.

Posesję w 1872 na publicznej licytacji kupił Henryk Piotrowski, co w pewnym stopniu naświetla sytuację finansową rodziny Boczarskich. W latach późniejszych właściciele zmieniają się kilkukrotnie nie wnosząc większych zmian w obiekcie, dopiero w 1899 roku dowiadujemy się, że miasto odkupiło część posesji na potrzeby regulacji ulicy Bernardyńskiej. W tym samym roku opracowano projekt przebudowy obiektu do stanu istniejącego z poszerzeniem budynku o część A, wykonaniem ryzalitów frontowych oraz oficyny tylnej. Dodatkowo w tym samym roku wykonano jeszcze jeden projekt na podwyższenie ryzalitów frontowych do trzech kondygnacji nadziemnych, projektu jednak nie zrealizowano. Prace zostały rozpoczęte jeszcze w tym samym roku. Kilka miesięcy później (w trakcie trwania budowy), wykonany został projekt podwyższenia ryzalitów frontowych o dodatkową kondygnację (projektu tego nie zrealizowano). W 1902 r. ukończono budowę niewielkiej oficyny od tyłu co w pełni ukształtowało dzisiejszą zabudowę. W 1964 r. miał miejsce „remont generalny”, który ograniczył się do „odświeżenia” wyglądu budynku, wymiany jednego stropu i prac zewnętrznych. W tym okresie prawdopodobnie rozebrano również murowany budynek na tyłach posesji. Na początku lat 80-tych XX w. wykonano schody do piwnicy w obu ryzalitach frontowych. W 1992 roku przeprowadzono remont pomieszczeń parteru na cele usługowe. W tym samym roku w trakcie burzy spadający konar drzewa zniszczył rzeźbę Kościuszki, która powróciła dopiero w 2006 r. W 2002 r. odtworzono ogrodzenie od strony ul. Bernardyńskiej. Obecnie stopniowo wykonywane są bieżące naprawy i remonty.

11 Właściciel pałacu Sobieskich oraz kamienicy przy Bramie Krakowskiej.

12 Wyłączając część A.

13 Obecnie nieistniejący.

14 APL, AML 1874-1915, 7204, str. 20-71. 


\section{OPIS OBIEKTU}

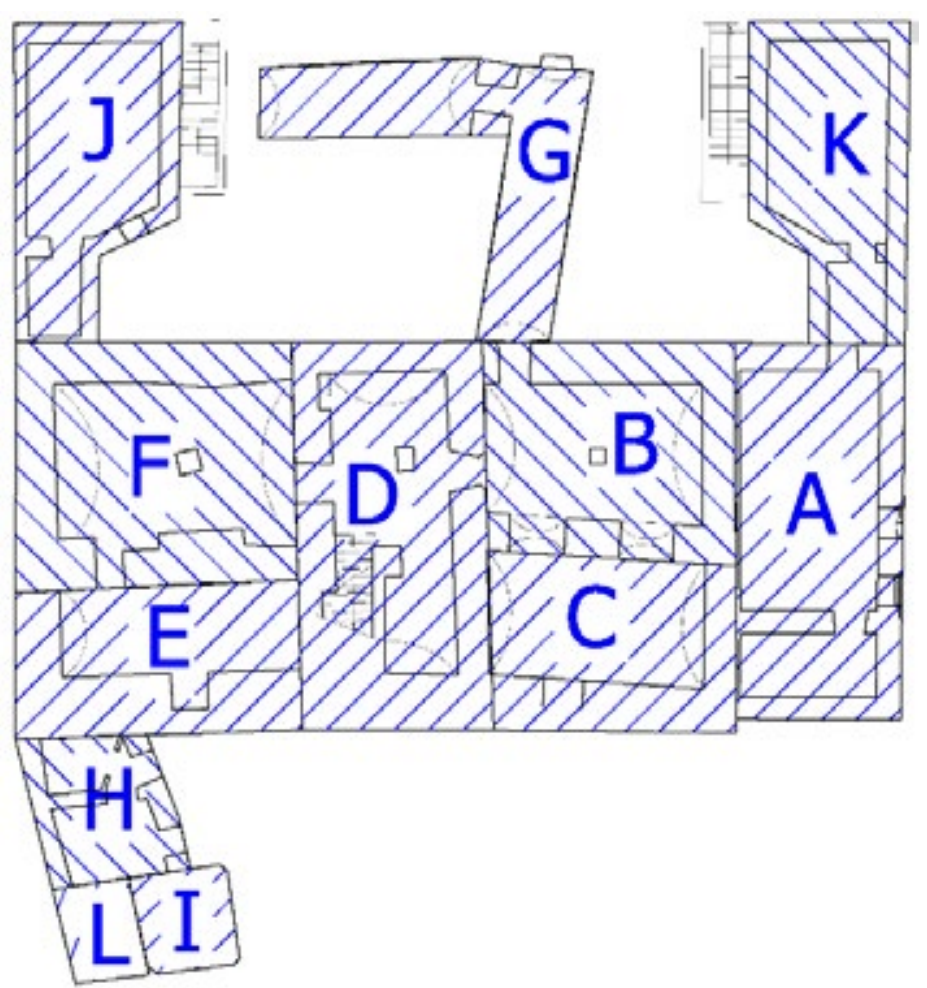

Ryc. 7. Oznaczenia budynku przyjęte w opisie. Rys. autor

Fog. 7. Description part of the building in paper, by author

Budynek posiada jedną kondygnację podziemną (wraz z dwoma kondygnacjami piwnic poza obrysem kamienicy) i trzy nadziemne, jest użytkowany i zamieszkały. Na poziomie piwnicy znajdują się pomieszczenia usługowe oraz komórki lokatorskie, na wyższych kondygnacjach usługi i mieszkania. Dla łatwiejszego opisu obiekt podzielono na jedenaście części (A-K).

Piwnice pod częścią A (przykryte drewnianym płaskim XIX-to wiecznym stropem, część była zamieszkała).

Piwnice pod ryzalitami frontowymi K, J (są użytkowane, przykryte stropem płaskim, otynkowane), powstały na przełomie XIX i XX wieku.

Część B-F w większości nie posiadają tynków, głównym elementem murowym ścian i sklepień jest opoka z przemurowaniami ceglanymi na zaprawie wapiennej. Pomieszczenia przykryte są sklepieniami kolebkowymi i kolebkowymi z lunetami w różnym układzie. Część ta wykorzystywana jest na potrzeby komórek lokatorskich, które wydzielone zostały ceglanymi i drewnianymi przepierzeniami.

Najciekawszym elementem tej części są trzy zachowane (a prawdopodobnie cztery istniejące) przejścia ostrołukowe wykonane z kamienia (Ryc. , Ryc. 11, Ryc. ). Elementy te powstały $\mathrm{w}$ trzecim okresie budowlanym. Wykonanie ścian pomiędzy częściami B-C i E-F, automatycznie wymusiło zamurowanie przejść do części D, wykonanych w drugim okresie. Obecnie przejścia te widoczne są fragmentarycznie w postaci opaski ceglanej (Ryc. 12). Otwory te wykonane zostały wtórnie przez wykucie ich w kamiennej ścianie i wbudowanie ościeży o grubości jednej cegły. Nie udało się określić kształtu ich łęków, które mogły mieć 
formę odcinka, łuku jak i ostrołuku ${ }^{15}$. Cztery słupy ceglane na poziomie piwnicy wykonano w XIX w. Tylko jeden z nich wzmacnia ściany i konstrukcję klatki schodowej. Pozostałe słupy nie przenoszą obciążeń innych jak ze sklepień. Na podstawie braku widocznych uszkodzeń lub spękań sklepień, przypuszczać można, że wzmocnienia te zostały dodane na potrzeby planowanej a niezrealizowanej przebudowy. Możliwym jest, że XIX-to wieczna przebudowa zasięgiem swym miała objąć znacznie większy zakres a ograniczyła się tylko do zmiany układu komunikacyjnego, ujednolicenia i usystematyzowania otworów okiennych na elewacji frontowej oraz dodaniu dwóch ryzalitów.

Część D, jako jedyna posiada inne ukierunkowanie sklepienia a na całej powierzchni widoczne są liczne naprawy i przemurowania cegłami pochodzącymi z różnych okresów. Przemurowania te oraz wypełnione komórki lokatorskie uniemożliwiają prawidłowe rozczytanie przekształceń tej części.

Część E i F ze względu na komórki lokatorskie oraz wtórne przemurowania, wzmocnienia konstrukcji pozostaje rozpoznana w najmniejszym stopniu. W części F widoczny jest zachowany fragment posadzki ceglanej, ostrołukowe przejście do części E. Najciekawszym, widocznym elementem jest zamurowany otwór, dodatkowo zasłonięty częściowo ścianą E-F ${ }^{16}$.

Część B-C jest analogiczna do części E i F. W ścianie pomiędzy częściami znajdują się dwa ostrołukowo sklepione otwory komunikacyjne oraz zamurowany otwór w ścianie z częścią D.

Część G jest nietynkowana, w całości wykonana z cegły ceramicznej (palcówki) na zaprawie wapiennej. Pomieszczenia zostały wykonane metodą drążeniową w XVII lub na początku XVIII w.

Na poziomie parteru i wyższych kondygnacjach znajdują się mieszkania i usługi. Wszystkie pomieszczenia są otynkowane, posiadają stropy płaskie (jedno pomieszczenie parteru posiada stop płaski z siestrzanem). Układ i podziały wewnętrzne są nieczytelne i zatarte poprzez wtórne podziały ściankami działowymi. Dopiero na drugim piętrze widoczny jest wyraźny układ kondygnacji (dodany na przełomie XIX i XX w). Otwory okienne elewacji frontowej zostały usystematyzowane $\mathrm{w}$ trakcie ostatniej przebudowy, na ich rozmieszczenie nie miał wpływu istniejący układ wnętrz liczył się jedynie wygląd elewacji, stąd niektóre okna są zablendowane (znajdują się „na wysokości” ścian) oraz podcięte i zdeformowane wnęki widoczne od wnętrza budynku.

15 Obecnie większa część łęku zasłonięta jest przez ścianę i nie jest możliwe jednoznaczne określenie jego kształtu. 16 Analogiczny otwór znajduje się w części B-C. 


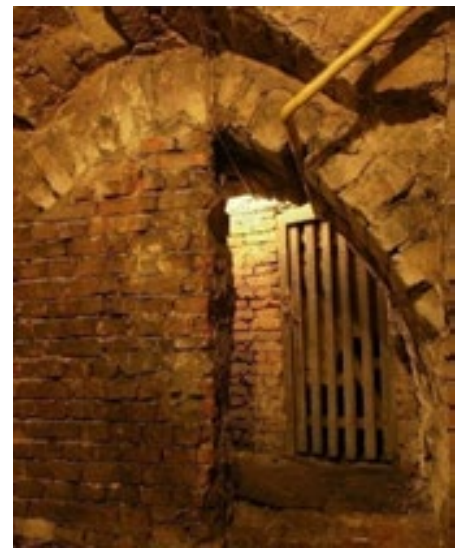

Ryc. 8. Piwnica, część F, przejście do części E. Fot. K. Janus

Fig. 8. Basement, part F, passage to part. E. Photo K. Janus

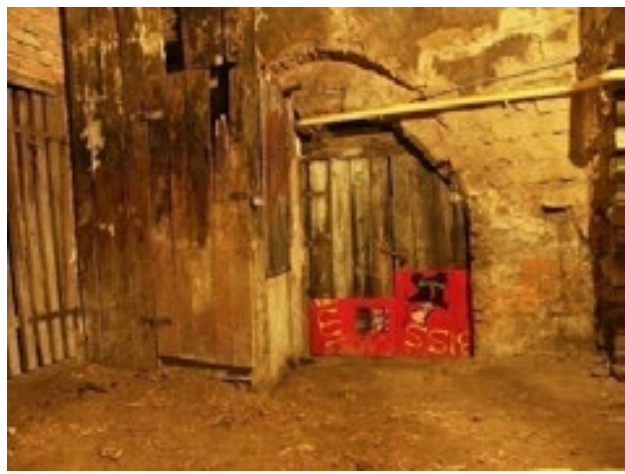

Ryc. 10. Piwnica, część B, przejście do części C. Fot. K. Janus

Fig. 10. Basement, part B, passage to part C. Photo K. Janus

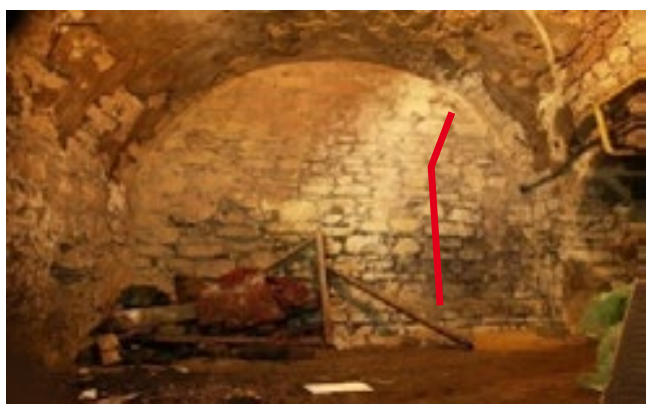

Ryc. 12. Piwnica, część C, widok na ścianę wschodnią z zaznaczeniem zamurowanego otworu. Fot. K. Janus

Fig. 12. Basement, part $\mathrm{C}$, the view on eastern wall with mark of the wall up opening. Photo K. Janus

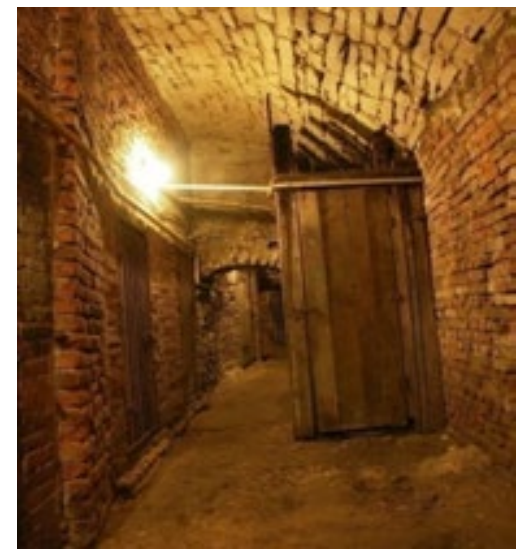

Ryc. 9. Piwnica, część F, widok na ścianę wschodnią. Fot. K. Janus

Fig. 9. Basement, part F, view on eastern wall. Photo K. Janus

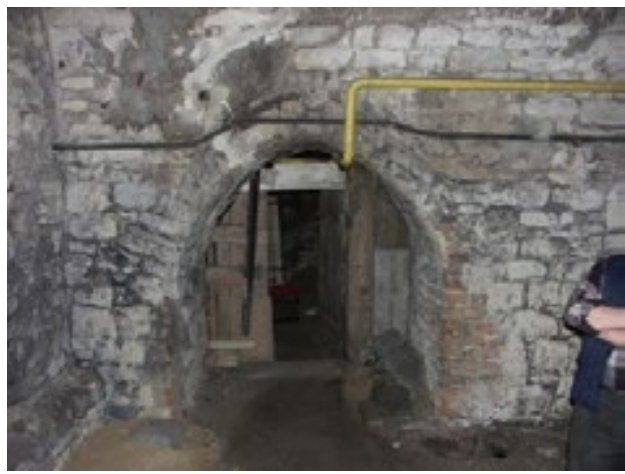

Ryc.11. Piwnica, część C, przejście do części B. Fot. K. Janus

Fig. 11. Basement, part C, passage to part B. Photo K. Janus

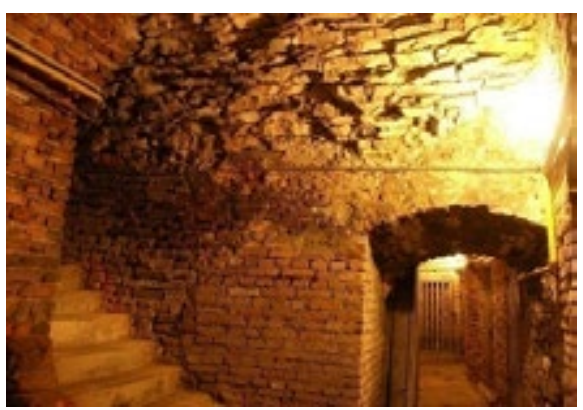

Ryc. 13. Piwnica, część D, widok na ścianę wschodnią. Fot. K. Janus

Fig. 13. Basement, part D, view on eastern wall. Photo K. Janus 


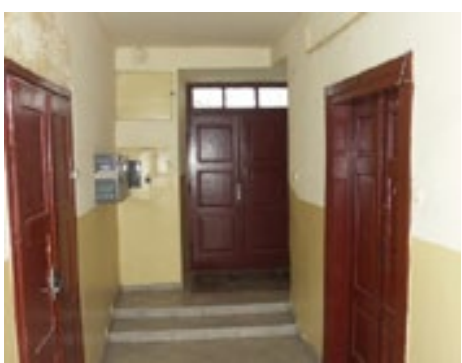

Ryc. 14. Parter, sień - widok na podcięty otwór wejścia głównego. Fot. K. Janus Fig. 14. Groun floor, hall - view on cut opening main entry. Photo K. Janus

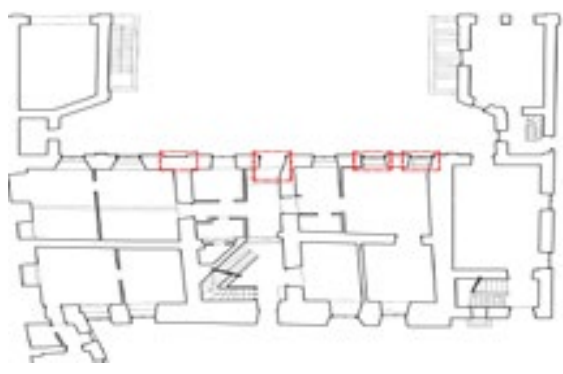

Ryc. 15. Rzut parteru z oznaczeniem modyfikowanych otworów. Fot. K. Janus

Fig. 15. Drawing ground floor with modified openings. Photo K. Janus

Układ ścian i okien współgra ze sobą dopiero na poziomie drugiego piętra. W ścianie od strony wschodniej znajdują się trzy wnęki, które zostały zamurowane po „doklejeniu” do ściany obiektów klasztoru bernardynek ${ }^{17}$. Nietypowym rozwiązaniem jest siestrzan, umieszczony niesymetrycznie. Może to świadczyć o mało precyzyjnym wykonawstwie lub też o modyfikacji ściany, na której oparty był strop pomieszczenia. Ściana pomiędzy częścią E i F została dodana zapewne wtórnie ${ }^{18}$. Ściana ta ma inne ukierunkowanie niż ściana piwnicy a przede wszystkim posadowiona jest na poniższym sklepieniu. Zastanawiającym jest fakt, że w przypadku gdyby ściana parteru była posadowiona na ścianie piwnicy wówczas siestrzan symetrycznie dzieliłby pomieszczenie na dwie części.

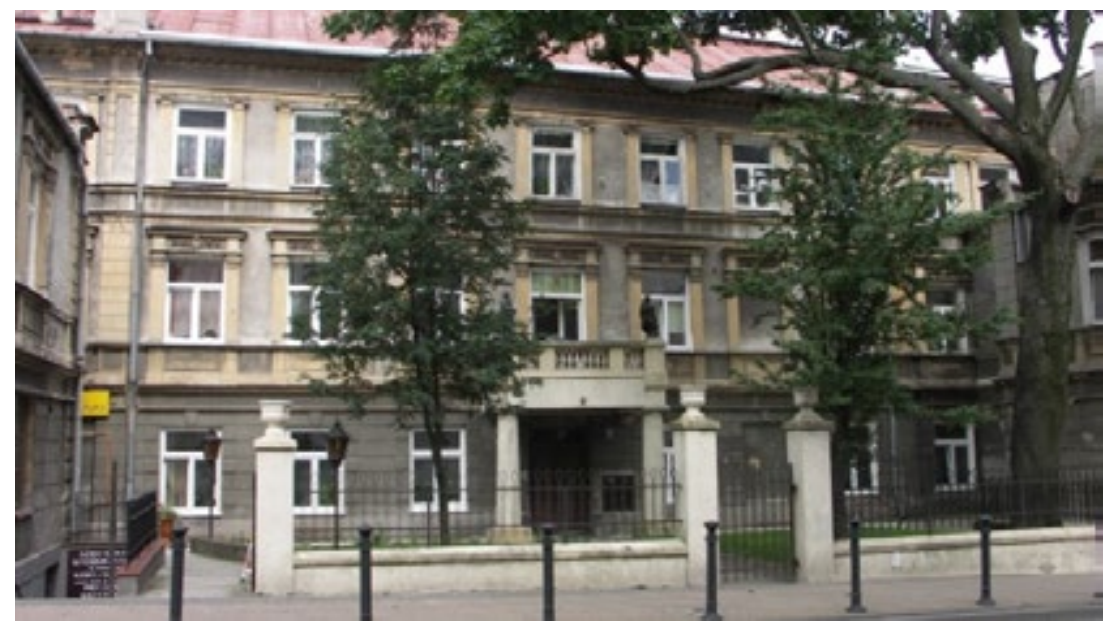

Ryc. 16. Elewacja frontowa. Fot. K. Janus

Fig. 16. Front fasade. Photo K. Janus

17 Fakt ten niemalże jednoznacznie stwierdza okres powstania ściany parteru przed 1650 rokiem oraz większą własność Gorajskich w kierunku wschodnim.

$18 \mathrm{Z}$ relacji mieszkańców wynika, że ściana wykonana jest w całości z cegły, a ściany zewnętrzne do wysokości I piętra $\mathrm{z}$ kamienia wapiennego. 


\section{PRÓBA ODTWORZENIA STRATYGRAFII OBIEKTU ${ }^{19}$}

Na podstawie danych historycznych wnioskować można, że pierwsze zabudowania murowane na omawianej działce powstały pomiędzy $1565-70$ rokiem, z inicjatywy rodziny Gorajskich. Pierwsza wzmianka historyczna pochodzi dopiero z 1602 roku, pierwsze graficzne przedstawienie z 1617 i $1649 \mathrm{r}$. a pierwszy opis z $1832 \mathrm{r}$.

Ukształtowanie terenu na omawianym obszarze znacznie różniło się od tego dzisiejszego. W przestrzeni pomiędzy ulicą Królewską, a Bernardyńską znajdował się wąwóz sięgający od Krakowskiego Przedmieścia aż do ulicy Wyszyńskiego i dalej w kierunku wschodnim do obszarów zalewowych. Obiekt najprawdopodobniej wzniesiony został częściowo na zboczu stoku wąwozu w taki sposób, że od frontu kondygnacja piwnicy znajdowała się pod ziemią a od strony wąwozu znajdowała się ponad jej powierzchnią ${ }^{20}$. Obecnie wąwóz został całkowicie zniwelowany. Jego kształt widoczny jest dopiero od posesji Bernardyńska 14a aż do ul. Wyszyńskiego ${ }^{21}$. Przez bardzo długi okres czasu wąwóz służył jako rynsztok odprowadzający ścieki poczynając od zabudowań przy Krakowskim Przedmieściu. Obecnie w jego pobliżu biegnie główna magistrala ściekowa.

Na podstawie badań archeologicznych i odwiertów geotechnicznych można określić kształt i lokalizację krawędzi wąwozu (co tłumaczyłoby potrzebę wykonania potężnego oskarpowania ścian). Na wysokości ulicy Bernardyńskiej less calcowy znajduje się na głębokości ok. 40 $\mathrm{cm}$ poniżej nawierzchni ${ }^{22}$, na podwórku frontowym poziom ten znajduje się na głębokości do $120 \mathrm{~cm}$ poniżej gruntu, na tylnym podwórku zalega warstwa nasypów o miąższości powyżej czterech metrów. Na tej podstawie można przypuszczać, że wąwóz mógł się kształtować jak przedstawiono na ( Ryc.17)

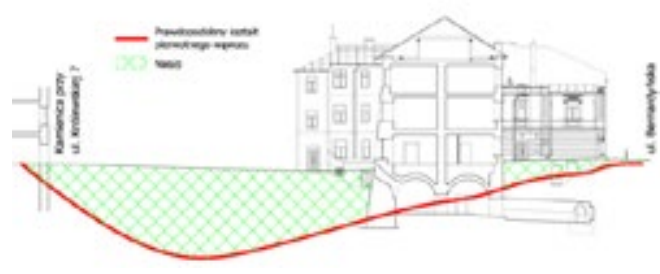

Ryc. 17. Przekrój terenowy z naniesionym prawdopodobnym kształtem zniwelowanego wąwoz. Rys. K. Janus

Fig. 17. Section by fild with shape of the former ravine, by aythor

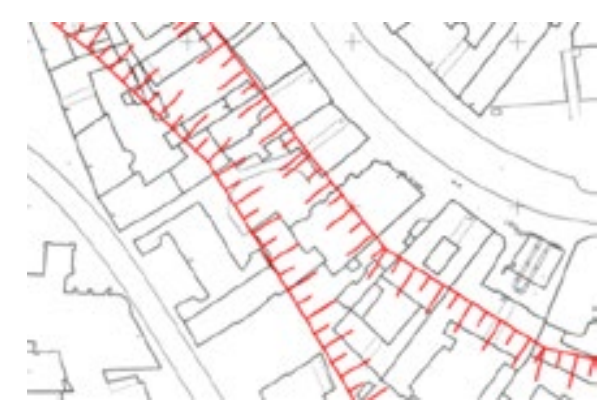

Ryc. 18. Prawdopodobny kształt nieistniejącego wąwozu pomiędzy ulicą Bernardyńska a Królewską. Rys. K. Janus

Fig. 18. Shape of the posible non-existent ravine between Bernardyńska and street Królewska, by author

19 Całą analizę obiektu oparto na oględzinach (głównie poziomu piwnicy), bez wykonywania odkrywek badawczych, posiłkowano się również badaniami stanu technicznego więźby dachowej oraz badaniami kolorystyki elewacji, są to jedyne opracowania badawcze wykonane na obiekcie. Pełne określenie faz przekształceń obiektu będzie możliwe po wykonaniu badań architektonicznych wszystkich kondygnacji obiektu, wspartych badaniami archeologicznymi, konserwatorskimi oraz geofizycznymi.

20 Sytuacja taka jest powtarzalną w tej części Lublina.

21 Na odcinku tym również nastąpiła niwelacja, a miąższość nasypów, wyznaczających obecne ukształtowanie terenu sięga 4 metrów.

22 Możliwe, że poziom rodzimego gruntu znajdował się wyżej a wzgórze to zostało „ścięte” w trakcie regulacji ulicy Bernardyńskiej lub wcześniej. 
Najstarszą zabudowę stanowi część „D”, powstała prawdopodobnie z inicjatywy Adama Gorajskigo. W etapie tym wzniesiony został jednotraktowy obiekt o szerokości sześciu i długości powyżej dwunastu metrów, szczytowo lokowany względem ulicy. Układ taki nie był najwygodniejszym i typowym rozwiązaniem. Obiekt w takiej formie, wydaje się stanowić zaledwie jedną część (może trakt większego założenia). Możliwe, że był to pierwszy etap budowlany lub też składał się $\mathrm{z}$ części murowanej i drewnianej. Z oględzin terenowych oraz zależności pomiędzy węzłami wynika jednoznacznie, że do części D dobudowane zostały oba skrzydła boczne. Wiążąc te dane ze sztychem Hogenberga/Brauna przypuszczać można, że w okresie tym obiekt był już piętrowy.

Niedługo później, ze względu na pełnioną funkcje zboru, okazało się, że jest za mały a obiekt rozbudowano o dodatkowe skrzydła wschodnie i zachodnie, połączone niemalże centralnie umieszczonymi otworami komunikacyjnymi. Otwory te wykonano wtórnie w ścianie części D z obmurowaniem ich cegłą. Nie jest jasne czy, oba skrzydła powstały jednocześnie czy etapami, co należałoby rozstrzygnąć w drodze badań. Części B, C i E, F w okresie tym były jeszcze jednoprzestrzenne. Przekryte stropem drewnianym z siestrzanem lub inną formą podpory ${ }^{23}$. Możliwym jest również, że bezpośrednio po wykonaniu skrajnych części zorientowano się, że rozpiętości pomieszczeń są za duże do przekrycia ich stropami i od razu wykonano ściany poprzeczne, na których oparte są obecnie sklepienia.

W kolejnym etapie budowlanym dodano podłużny podział na poziomie piwnicy i wykonano na nowo powstałej ścianie sklepień. Nie jest zrozumiałe, co kierowało budowniczymi, by stworzyć tak nieregularny podział, który wymusił zamurowanie dwóch otworów ${ }^{24}$. Nie rozpoznano również z jakiej przyczyny w nowo powstałej ścianie zastosowano ostrołukowo sklepione przejścia o szerokości ok. 2 m. Przypuszczać można, że otwory te służyły do swobodnego przepływu magazynowanych towarów dużych gabarytów, jednak nie udało się ustalić w jaki sposób przedmioty te dostarczano na poziom. Nie udało się również jednoznacznie umiejscowić pierwotnej klatki schodowej, łączącej poziom parteru z piwnicą ${ }^{25}$. W okresie tym najprawdopodobniej powstały obecnie istniejące sklepienia. Etap ten w zasadniczej formie ukształtował wygląd i układ podziału obecnej kamienicy na poziomie piwnicy, poza częścią A, która została dodana w XIX-tym wieku.

W 1649 roku obiekt został przedstawiony jako budynek dwukondygnacyjny z wydatnym ryzalitem, kryty dachówką. W pierwszej chwili wydaje się, że w skład przedstawionego obiektu wchodzi część B, D, F, jednak w takiej formie obiekt byłby mało funkcjonalny i nie odpowiadałby ówczesnym standardom. Najprawdopodobniej przedstawiony ryzalit został rozebrany, o czym świadczy węzeł pomiędzy częścią C, D i ścianą północną. W miejscu tym ściana zewnętrzna wyraźnie dostawiona jest do wewnętrznej ściany poprzecznej, widoczne są jej modyfikacje w tym punkcie ${ }^{26}$.

Nie wiemy jak w okresie tym kształtował się układ nadziemia, ale przypuszczać można, że obiekt był dwukondygnacyjny.

23 Rozpiętość tak powstałych części wynosi 7 i 8 m, przy takiej rozpiętości konieczne jest wsparcie pośrednie stropu poprzez siestrzan ze słupami, ścianę nośną, itp. w przypadku przekrycia pomieszczeń sklepieniem należało by zastosować pośrednią ścian i pomieszczenia przekryć sklepieniami w przeciwnym przypadku wysokość kondygnacji wahałaby się w granicach $4-5 \mathrm{~m}$.

24 Możliwe było wykonanie ścian bez konieczności ich zamurowania.

25 Ze względu na ukształtowanie terenu wejście do piwnicy mogło znajdować się od strony wąwozu a wejście na poziom parteru od strony ulicy Bernardyńskiej, kondygnacje w takiej sytuacji nie musiały być połączone, co należałoby rozstrzygnąć $\mathrm{w}$ drodze badań architektonicznych.

26 Do pełnej weryfikacji węzłów należało by wykonać badania architektoniczne oraz badania georadarowe, celem identyfikacji możliwości istnienia murów poniżej poziomu gruntu nieistniejącego obecnie ryzalitu. 
Dwór w swej historii kilkukrotnie przeżywał upadki, jednak za każdym razem powracał do życia ${ }^{27}$. Nie wiadomo jak wyglądał pomiędzy 1650 a 1780 rokiem, wiadomym jest, że pod koniec XVIII wieku popadł w ruinę.

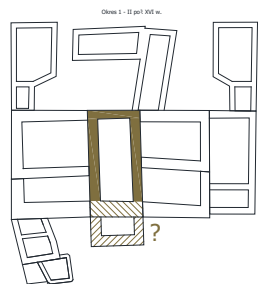

Ryc. 19. Faza I zabudowy II poł. XVI w.

Fig. 19. I Phase - II half XVI c

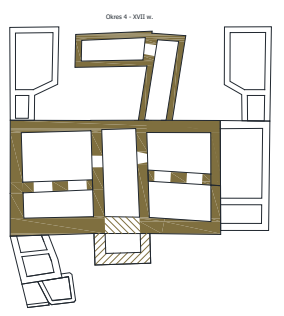

Ryc. 22. Faza IV zabudowy - XVII w.

Fig. 22. IV Phase - II half XVI c

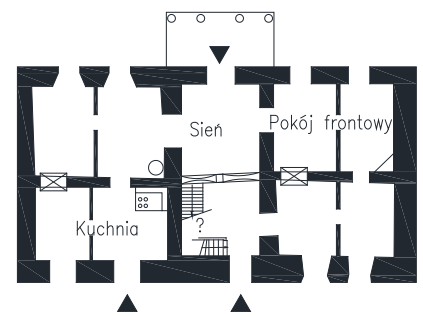

Ryc. 25. Próba rekonstrukcji poziomu parteru na podstawie opisu pożarowego z $1858 \mathrm{r}$.

Fig. 25. Trial of the reconstruction ground floor from historical-fire description 1858

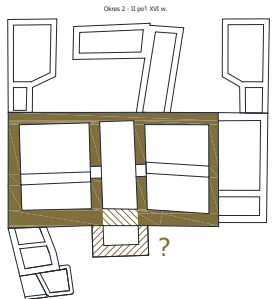

Ryc. 20. Faza II zabudowy II poł. XVI w.

Fig. II Phase - II half XVI c

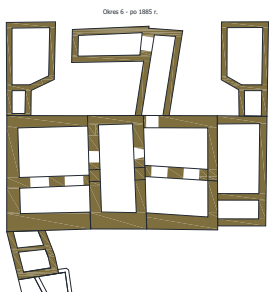

Ryc. 23. Faza V zabudowy ok. 1899 r.

Fig. 23. Phase-

II half XVI 1899

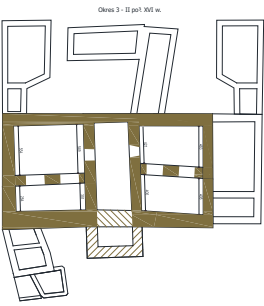

Ryc. 21. Faza III zabudowy II poł. XVI w

Fig. 21. III Phase - II half XVI c

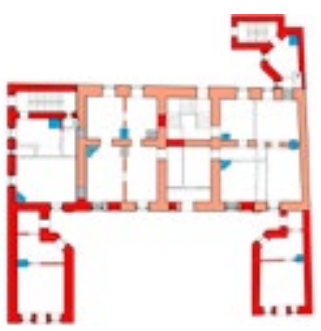

Ryc. 24. Projekt przebudowy obiektu z 1899 r.

Fig. 24. Project of rebuilding 1899

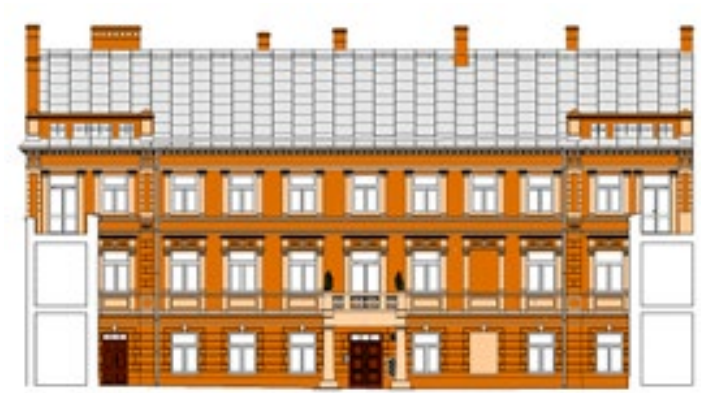

Ryc. 26. Rekonstrukcja kolorystyki elewacji z początku XX w. Fig. 26. Reconstruction of the elevation's color XX c 
Wiek XIX-ty przyniósł obiektowi sporo zmian oraz ukształtował jego dzisiejszy wygląd. W 1823 r. budynek był murowany, podpiwniczony, posiadał sień (D), dwie izby (B, F), dwa pokoje $(\mathrm{C}, \mathrm{E})$ oraz nieukończone pierwsze piętro. Wzorując się tylko na oszacowaniu pożarowym z 1858 roku wykonano rekonstrukcję poziomu parteru (Ryc. 25).

W roku 1899 rozpoczęto przebudowę obiektu, w wyniku której dobudowano część A, całość budynku podwyższono o jedną kondygnację, elewacji nadano obecny, jednolity wygląd (z żywą kolorystyką). Ponadto dodano dwa symetryczne frontowe ryzality (z tarasami). Projekt remontu od realizacji różni się w detalach, mianowicie w inny sposób niż w projekcie rozwiązano klatkę schodową, część ścian konstrukcyjnych, przewidziano elewację sześcioosiową, wykonano jedenastoosiowa. Całość przebudowy była zasługą rodziny Waśniewskich.

$\mathrm{Z}$ początkiem XX wieku dwór przekształcił się już całkowicie w kamienice mieszkalną. Obecnie w nazewnictwie nie występuje dwór Gorajskich, ani Gorajszczyzna.

\section{WNIOSKI}

Na podstawie oględzin zewnętrznych i wewnętrznych, uwzględniając ubogie dane historyczne, liczne nieudokumentowane pożary, wojny, plagi oraz zmiany własnościowe, na podstawie analizy materiałów wnioskować należy, że obiekt byłego dworu Gorajskich w Lublinie zachował bardzo wiele cennej substancji zabytkowej. Najwięcej oryginalnej i najmniej przekształconej zabudowy zachowało się na poziomie piwnicy ale i wyższych kondygnacjach.

Zabudowa sięga historią swą co najmniej wieku XVI-tego. Na poziomie piwnicy widoczne są liczne ślady zmian i przekształceń życia obiektu (w szczególności ostrołukowo sklepione otwory). Poziom piwnicy bardzo dobrze zachował zarówno oryginalną substancję zabytkową jak i uwidocznił poszczególne fazy przekształceń. Na poziomie parteru nie udało się określić rodzaju elementów murowych a analizę wykonano jedynie na podstawie układu i oględzin ścian. Drugie piętro, równolegle z frontowymi ryzalitami, częścią A oraz wystrojem elewacji zostało wykonane na przełomie XIX i XX wieku. Uwzględniając jedynie modyfikacje istniejących otworów, sądzić można, że w obiekcie na poziomie parteru i pierwszego piętra zachowała się najstarsza substancja zabytkowa z pierwszych okresów istnienia budynku a pod warstwą tynku zachowały się pierwotne podziały i układ elewacji z okresu Gorajskich. Obiekt ciągle kryje bardzo wiele tajemnic ale dzięki temu, że od wieku XVII nie został w znacznym stopniu przekształcony a XIX-to wieczna przebudowa polegała na dodaniu do istniejącego obiektu nowych skrzydeł i kondygnacji. Przypuszczać można, że obiekt dworu Gorajskich może stanowić jeden z najpełniej zachowanych i najmniej zniszczonych XVI-to wiecznych obiektów, jakich było wiele w tym okresie w tej „magnackiej dzielnicy” Lublina. Obiekt należy traktować z należytym szacunkiem a w przyszłości dokładnie przebadać, co pozwoli na poszerzenie wiedzy na temat XVI-to wiecznych dworów lubelskich. 


\section{PIŚMIENNICTWO}

Winiarczyk B., Boruch W., 1994. Kamienica przy ul. Bernardyńskiej 12 w Lublinie, Rozpoznanie historyczne

Radzik T., Witusik A., 1997. Lublin w dziejach i kulturze Polski, Polskie Towarzystwo Historyczne. Oddział: Krajowa Agencja Wydawnicza, Lublin

Archiwum Państwowe w Lublinie, RGL 1867-1918, UWL

WBP im. H. Łopacińskiego, Dziat Zbiorów Specjalnych

www.tnn.pl

\section{FORMER GORAJSKI'S MANOR IN 12 BERNARDYŃSKA ST. LUBLIN}

Abstract. Paper gives an introductions to complicated history of building former Gorajski's manor in 12 Bernardyńska St. Lublin. Described well-known and new facts and historical documents of building live. Consider to know study work and projeckts and own study and examination was possible to create architectural analysis, with making stratigraphy and transformations phase of the building. It allowed to place the Gorajski's manor as one of unremembered but still preserved magnate manors build in XVII century in Żmigrod.

Key words: Bernardyńska st. Gorajski’s manor, Ravine between Bernardyńska and Królewska street, Architektonical study 